\title{
Kompetensi Pedagogik Guru Pendidikan Agama Islam Sekolah Menengah Atas
}

\author{
Irvina Zulvah \\ SMA 1 Bringin Kecamatan Bringin Kabupaten Semarang \\ Email: irvinaspirit@gmail.com
}

\begin{abstract}
Abstrak
Penelitian ini bertujuan untuk mengetahui realitas upaya guru Pendidikan Agama Islam (PAI) dalam meningkatkan kompetensi pedagogik di sekolah menengah atas (SMA) se-Kecamatan Bringin, Kabupaten pada tahun 2012, termasuk: (1) Untuk menentukan kompetensi pedagogik guru PAI, (2) Untuk mengetahui upaya guru PAI dalam meningkatkan kompetensi pedagogik, (3) Untuk mengetahui pelaksanaan kompetensi pedagogic guru PAI se-Kecamatam Bringin. Penilaian dilakukan penelitian kualitatif, informan terdiri dari guru PAI dan kepala sekolah. Penelitian ini menggunakan pendekatan deskriptif dengan metode kualitatif. Kesimpulan dari penelitian ini adalah (1) kompetensi pedagogik guru PAI SMA se-Kecamatan Bringin Semarang 2012 tergolong baik, terbukti dari latar belakang pendidikan guru yang linier dengan pelajaran yang diampu, pemahaman terhadap kompetensi pedagogik yang baik, persiapan alat pembelajaran dan manajemen pembelajaran yang sesuai dengan ketentuan (2) upaya untuk meningkatkan kompetensi pedagogik adalah dengan memperbanyak referensi mengenai kompetensi pedagogik PAI, menghadiri berbagai seminar, lokakarya, pelatihan, dan mengikuti Musyawarah Guru Mata Pelajaran (MGMP). Pihak sekolah juga melakukan upaya melalui evaluasi belajar, memeriksa pembelajaran, supervisi kelas, dan mendorong guru untuk menghadiri seminar pendidikan (3) Pelaksanaan pedagogik pembelajaran pendidikan Islam akan menentukan kualitas
\end{abstract}


Mudarrisa: Jurnal Kajian Pendidikan Islam, Vol. 5, No.2, Desember 2013: 270-298

pembelajaran itu sendiri, dengan guru yang memiliki kompetensi pedagogik, manajemen pembelajaran akan berjalan lancar.

This study aims to determine the reality of the efforts of teachers of Islamic religious education (PAI) in improving pedagogic competence at senior high school (SMA) throughout Bringin Semarang regency in 2012, including: (1) To determine the pedagogical competence of PAI teachers, (2) To know the efforts of PAI teacher in improving pedagogical competence, (3) To know the implementation of pedagogical competence in PAI. The assessment was conducted qualitative research to informants, both PAI teacher and the headmaster. This study uses a descriptive qualitative procedure. The conclusions are (1) pedagogical competence of PAI teachers at SMA 1 Bringin Semarang Regency 2012 is good, proven by the teachers' linear education background with teaching load, understanding towards good pedagogic, the preparation of learning tools and management in accordance with the provisions (2) efforts to improve pedagogical competence are by reading various reference regarding it, attending seminars, workshops, trainings, and following deliberation subject teachers (MGMP), the school authorities make efforts through the evaluation of learning, classroom supervision, and creating opportunities for teachers to attend educational seminars (3) Implementation of pedagogic on learning Islamic education will determine the quality of learning itself. With teachers who have pedagogic competence, learning management will go smoothly.

Kata kunci: kompetensi pedagogic, guru PAI, SMA

\section{Pendahuluan}

Perhatian terhadap masalah pendidikan dewasa ini semakin lama semakin meningkat. Usaha-usaha positif untuk memperbaiki seluruh unsur dan komponen dalam pendidikan guna meningkatkan kuantitas dan kualitas pendidikan di Indonesia dilaksanakan secara sistematis dan berencana berdasarkan konsep pendidikan yang menyeluruh. Pendidikan sebagai salah satu lembaga untuk mencerdaskan bangsa, sudah 
selayaknya secara terus-menerus mengalami pembaharuan yang baik. Mulai dari managemen pendidikan, kurikulum, strategi, metode, ataupun evaluasi perlu untuk ditingkatkan agar tujuan pendidikan dapat tercapai sesuai dengan kebutuhan siswa yang memiliki karakteristik yang berbeda-beda antara satu siswa dengan siswa lainnya. Berbagai komponen yang saling terkait dengan lembaga pendidikan tesebut, pendidik memegang peranan penting dalam membimbing dan mengantarkan keberhasilan peserta didik. Karena langsung berhadapan dengan siswa di kelas. Maka sudah semestinya jika pendidik mempunyai kemampuan (kompetensi) tertentu yang disyaratkan agar dalam pelaksanaannya mengelola kelas bisa berjalan dengan baik.

Kompetensi guru merupakan salah satu kompenen yang harus dimiliki oleh setiap guru dalam jenjeng pendidikan apapun. Dalam hal ini, Mulyasa mengemukakan kompetensi guru merupakan perpaduan antara kemampuan personal, keilmuan, teknologi, sosial dan spiritual yang secara kaffah membentuk standar kompetensi standar kompetensi profesi guru, yang mencakup penguasaan materi, pemahaman terhadap peserta didik, pembelajaran yang mendidik, pengembangan pribadi dan profesionalisme (Mulyasa, 2008:26).

Guru merupakan komponen paling menentukan dalam sistem pendidikan secara keseluruan, yang harus mendapat perhatian khusus dan utama terutama dalam bidang kompetensi yang harus dimiliki seorang pendidik. Figur yang satu ini akan senangtiasa menjadi sorotan yang setrategis ketika berbicara masalah pendidikan, karena guru selalu terkait dengan komponen manapun dalam sistem pendidikan. Oleh karena itu, 
upaya perbaikan apapun yang dilakukan untuk meningkatkan kualitas pendidikan akan memberikan sumbangsih bagi dunia pendidikan kedepannya. Permasalahan yang timbul kecakapan atau kompetensi guru yang kurang baik menjadi salah satu faktor penentu keberhasilan dalam pendidikan terlebih kompetensi yang dimikliki guru pendidikan agama Islam, yang menjadi pendidik akhlak yang bersumber pada ajaran-ajaran agama, terutama peserta didik yang tinggal kebanyakan didaerah pinggiran seperti halnya wilayah Kecamatan Bringin Kabupaten Semarang. Berdasarkan latar belakang masalah tersebut di atas maka timbullah keinginan penulis untuk mengangkat permasalahan ini dalam sebuah karangan ilmiah dengan menetapkan sebagai judul adalah “Kompetensi Pedagogik Guru Pendidikan Agama Islam di Sekolah Menengah Atas se-Kecamatan Bringin Kabupaten Semarang Tahun 2012"

Berdasarkan wacana diatas, penelitian ini akan mengamati bagaimana kompetensi pedagogik guru PAI di SMA se-Kecamatan Bringin Kabupaten Semarang Tahun 2012, dan bagaimana upaya para guru PAI di SMA se-Kecamatan Bringin tahun 2012 dalam meningkatkan kompetensi pedagogik, serta Bagaimanakah implementasi kompetensi pedagogik pada pembelajaran PAI pada SMA se-Kecamatan Bringin tahun 2012.

\section{Metode Penelitian}

Setiap penelitian memerlukan pendekatan dan jenis penelitian yang sesuai dengan masalah yang dihadapi. Jenis penelitian yang 
dipergunakan dalam penelitian ini adalah pendekatan kualitatif. Penelitian kualitatif mengkaji perspektif partisipan dengan multi strategi, strategi-strategi yang bersifat interaktif, seperti observasi langsung, observasi partisipan, wawancara mendalam, dokumen-dokumen, teknikteknik perlengkapan seperti foto, rekaman, dan lain-lain (Nurul Zuriah, 2006:95).

Penelitian yang akan dilakukan oleh peneliti merupakan penelitian yang bersifat kualitatif dan menggunakan metode deskriptif. Permasalahan utama yang dibahas dalam sekripsi ini untuk mengetahui upaya guru pendidikan agama Islam dalam meningkatkan kompetensi pedagogik di sekolah menengah atas se-Kecamatan Bringin Kabupaten Semarang Tahun 2012.

Dalam penelitian ini peneliti bertindak sebagai instrumen sekaligus pengumpul data. Peneliti datang dan secara langung berinteraksi ditengah-tengah objek penelitian dan melakukan pengamatan, wawancara mendalam dan aktivitas-aktivitas lainnya demi memperoleh data-data yang diperlukan dalam penelitian ini. Peneliti turun langsung ke kancah penelitian, tanpa mewakilkan pada orang lain, agar kegiatan yang berkaitan dalam menggali, mengidentifikasi data informasi dan fenomena yang muncul dilapangan dapat diperoleh secara akurat.

Sumber data diperoleh dari sumber primer dan sumber sekunder. Sumber primer diantaranya guru pendidikan agama Islam di sekolah menengah atas se-Kecamatan Bringin. Sedangkan sumber sekunder diantaranya tenaga kependidikan lain seperti: kepala sekolah dan staf 
yang berada di sekolah menengah atas se-Kecamatan Bringin serta sumber-sumber lain yang bisa dijadikan reverensi seperti dokumendokumen maupun surat-surat penting.

Prosedur pengumpulan data yang digunakan dalam penelitian ini adalah wawancara, observasi dan dokumentasi. Wawancara adalah tanya jawab dengan seseorang yang diperlukan untuk dimintai keterangan atau pendapat mengenai suatu hal (Kamus Besar Bahasa Indonesia Edisi Ketiga, 2007:1270). Teknik wawancara dilakukan untuk memperoleh informasi sebanyak mungkin secara jujur dan detail. Teknik wawancara digunakan untuk menggali data dari guru pendidikan agama Islam tentang upaya meningkatkan kompetensi pedagogik guru pendidikan agama Islam. Observasi adalah peninjauan secara cermat (Kamus Besar Bahasa Indonesia Edisi Ketiga, 2007:794). Metode ini dilakukan untuk mengetahui dan mengamati secara langsung tentang aktivitas guru pendidikan agama Islam yang berkaitan dengan upaya peningkatan kompetensi pedagogik guru pendidikan agama Islam. seperti, keberadaan rencana pelaksanaan pembelajaran (RPP) dan silabus, serta ketersediaan sarana dan media pembelajaran. Dokumentasi adalah metode penelitian ditujukan pada penguraian dan penjelasan apa yang telah lalu melalui sumbersumber dokumen (Surakhmad, 1985:132). Metode ini dimaksudkan untuk mencari data berupa dokumentasi perencanaan pembelajaran yang meliputi silabus dan rencana pelaksanaan pembelajaran (RPP), foto-foto, gambar, dokumen, notulen rapat, catatan harian, agenda dan sebagainya yang dapat dijadikan reverensi dalam penelitian. 
Analisis data dalam penelitian kualitatif adalah proses pelacakan dan pengaturan secara sistematis transkip wawancara, catatan lapangan, dan bahan-bahan lain yang dikumpulkan untuk meningkatkan pemahaman terhadap bahan-bahan tersebut agar dapat diinterpretasikan temuannya kepada orang lain (Nurul Zuriah, 2006:217). Dalam analisis data peneliti mempelajari suatu masalah yang diteliti secara mendasar dan mendalam dengan prosedur analisis:penyusunan data, pengolahan data dengan mengklasifikasikan data kedalam kategori-kategori yang jumlahnya lebih terbatas sesuai dengan data yang diperlukan, organisasi data, pemilahan menjadi satuan-satuan tertentu dan penemuan hal-hal yang penting untuk dipelajari. Dalam penelitian ini analisis data dilakukan selama dan setelah pengumpulan data.

Pada tahap pengecekan keabsahan data peneliti banyak terlibat dalam kegiatan penyajian atau penampilan dari data yang dikumpulkan dan dianalisis sebelumnya (Nurul Zuriah, 2006:219). Dalam pengecekan keabsahan data peneliti menggunakan teknik-teknik perpanjangan kehadiran penelitian dilapangan, observasi yang diperdalam dengan melakukan kroscek dengan beberapa sumber lain yang terkait. Dalam tahap-tahap penelitian menguraikan proses pelaksanaan penelitian diantaranya: Penelitian pendahuluan yaitu penyusunan proposal dan perencanaan penelitian, pengembangan desain, penelitian sebenarnya dimana peneliti hadir langsung di lokasi penelitian, dan penulisan laporan. 


\section{Pembahasan}

\section{A. Hakikat Guru}

Guru adalah pendidik profesional dengan tugas utama mendidik, mengajar, membimbing, mengarahkan, melatih, menilai dan mengevaluasi peserta didik pada pendidikan anak usia dini jalur pendidikan formal, pendidikan dasar dan pendidikan menengah (Undangundang Republik Indonesia Nomor 14 tahun 2005 tentang guru dan dosen Pasal 01, 2005:2).

Status guru mempunyai implikasi terhadap fungsi yang menjadi tanggung jawabnya. Sebagai profesi yang bertugas mendidik, mengajar, melatih, dan membimbing peserta didik guna mengantarkan peserta didik memperoleh ilmu pengetahuan dan mewujudkan tujuan pendidikan nasional. Guru memiliki satu kesatuan peran dan fungsi yang tidak terpisahkan, antara kemampuan mendidik, membimbing, mengajar, dan melatih. Keempat kemampuan tersebut merupakan kemampuan intregatif, antara yang satu dengan yang lain tidak dapat dipisahkan (Suparlan, 2005:25).

Guru adalah komponen yang menjadi salah satu penentu dalam sistem pendidikan secara keseluruan yang memiliki tugastugas pokok, diantaranya adalah mengetahui latar belakang, sosial ekonomi, dan intelektual akademis siswa,vmengetahui perbedaan individu siswa, potensi, dan kelemahan siswa, termasuk pembelajaran mereka, memiliki pengetahuan, terampil, dan professional, bertanggung jawab, disiplin, dan produktif, menghargai dan kasih saying terhadap siswa, memiliki nilai-nilai moral, prinsip kemanusiaan dalam semua langkahnya, 
memiliki sikap inovatif, kreatif, dan memahami perbedaan individualitas dikalangan siswa, menjadi contoh model bagi siswa, apa yang dikatakan itulah yang dilakukan, serta menghargai dan peduli terhadap lingkungan dan memahami perkembangan dan penerapan ilmu pengetahuan dan teknologi dalam kehidupan modern (suparlan, 2005:330)

Dalam undang-undang guru dan dosen Nomor 14 tahun 2005 dinyatakan tentang hak-hak pendidik dan tenaga kependidikan sebagai berikut: memperoleh penghasilan di atas kebutuhan hidup minimum dan jaminan kesejahteraan sosial, mendapat promosi dan penghargaan sesuai dengan tugas dan prestasi kerja, memperoleh perlindungan dalam menghasilkan tugas dan hak atas kekayaan intelektual, memperoleh kesempatan untuk meningkatkan kompetensi, memperoleh dan memanfaatkan sarana dan prasarana pembelajaran untuk menunjang kelancaran tugas professional, memiliki kebebasan dalam memberikan penilaian dan ikut menentukan kelulusan, penghargaan, dan atau sangsi kepada peserta didik sesuai dengan kaidah pendidikan, kode etik guru, dan peraturan perundang-undangan, memperoleh rasa aman dan jaminan keselamatan dalam melaksanakan tugas, memiliki kebebasan untuk berserikat dalam organisasi profesi, memiliki kesempatan untuk berperan dalam menentukan kebijakan pendidikan, memperoleh kesempatan untuk mengembangkan dan meningkatkan kualifikasi akademik dan kompetensi dan, memperoleh pelatihan dan pengembangan profesi dalam bidangnya (undang-undang republik indonesia nomor 14 tahun 2005 tentang guru dan dosen pasal 14, 2005:9). 
Hak-hak tersebut dalam kenyataannya mungkin masih dalam bentuk harapan dan belum menjadi kenyataan. Untuk menggapai harapan tersebut sudah barang tentu memerlukan usaha dan terus-menerus dan pantang menyerah. Hak-hak yang akan diperoleh tersebut barulah setara apabila diimbangi dengan kewajiban yang diberikan dalam pelaksanaan tugasnya. Dalam undang-undang yang sama dinyatakan lebih lanjut bahwa pendidik dan tenaga kependidikan memiliki kewajiban sebagai berikut: merencanakan pembelajaran, melaksanakan proses pembelajaran yang bermutu, serta menilai dan mengevaluasi hasil pembelajaran, meningkatkan dan mengembangkan kualifikasi akademik dan kompetensi secara berkelanjutan sejalan dengan ilmu penegetahuan, teknologi dan seni, bertindak objektif dan tidak diskriminatif atas dasar pertimbangan jenis kelamin, agama, suku, ras dan kondisi fisik tertentu atau latar belakang keluarga, dan status sosial ekonomi peserta didik dalam pembelajaran, menjunjung tinggi peraturan perundang-undangan, hokum dan kode etik guru serta nilai-nilai agama dan etika, serta memelihara dan memupuk persatuan dan kesatuan bangsa undangundang republik indonesia nomor 14 tahun 2005 tentang guru dan dosen pasal 20, 2005:11)

Kode etik suatu profesi merupakan norma-norma yang harus diindahkan dan diamalkan oleh setiap anggotanaya dalam pelaksanaan tugas dan pergaulan hidup sehari-hari dimasyarakat. Norma-norma tersebut berisi petunjuk-petunjuk bagaimana mereka melaksanakan profesinya, dan larangan-larangan, tentang apa yang tidak boleh diperbuat atau dilaksanakan, tidak saja dalam melaksanakan tugas 
profesi, tetapi dalam pergaulan hidup sehari-hari didalam masyarakat (Mulyasa, 2008:43). Dengan kata lain, kode etik guru adalah normanorma dan etika yang mengikat guru dalam pelaksanaan tugas keprofesionalan, yang mengatur hubungan kemanusiaan antara pendidik dan peserta didik, orang tua peserta didik, maupun dengan atasannya. Tujuan perumusan kode etik suatu profesi adalah untuk kepentingan anggota dan kepentingan organisasi profesi itu sendiri, secara umum tujuan pengadaan kode etik adalah menjunjung tinggi martabat profesi, untuk menjaga dan memelihara kesejahteraan anggotanya, pedoman berperilaku, untuk meningkatkan pengandian para anggota profesi, untuk meningkatkan mutu profesi, untuk meningkatkan mutu organisasi profesi (mulyasa, 2008: 44).

Nugroho Notosusanto berpendapat bahwa di dunia ini hanya ada dua jabatan yaitu : jabatan guru dan jabatan non guru. Yang membedakan jabatan keduanya adalah mengajar. Mengajar merupakan langkah seorang guru untuk memandaikan bangsa dengan tanpa memikirkan efek untung dan ruginya secara material-personal, melainkan memikirkan bagaimana nistanya jika generasi selanjutnya tidak lebih berkualitas dalam semua aspek kehidupan. Aktivitas mengajar tersebut tentunya menuntut kepekaan emosional dan spiritual yang mampu melahirkan mentalitas dan moralitas suatu bangsa.

Guru merupakan pendidik profesional dengan tugas utama mendidik, mengajar , membimbng, mengarahkan, melatih, menilai, dan mengevaluasi peserta didik pada jalur pendidikan formal. Tugas utama itu akan efektif jika guru memiliki derajat profesionalitas tertentu yang 
tercermin dan kompetensi, kemahiran, kecakapan, atau keterampilan yang memenuhi standar mutu atau norma etik tertentu.

Di negara ini guru dibagi menjadi dua yaitu guru negeri dan guru swasta. Guru negeri berada dalam struktur pemerintahan dan digaji oleh pemerintah, sedang guru swasta mendapat pembinaan dari pemerintah dan mendapat gaji dari sekolahnya masing-masing.

Jabatan guru memiliki banyak tugas, baik yang terikat oleh dinas maupun di luar dinas dalam bentuk pengabdian. Tugas guru tidak hanya sebagai profesi, tetapi juga sebagi suatu tugas kemanusiaan dan kemasyarakatan.

Tugas guru sebagai suatu profesi menuntut kepada guru untuk mengembangkan profesionalitas diri sesuai perkembangan ilmu pengetahuan dan teknologi. Mendidik, mengajar, dan melatih peserta didik adalah tugas guru sebagai suatu profesi. Tugas guru sebagai pendidik berarti meneruskan dan mengembangkan nilai-nilai hidup pada peserta didik. Tugas guru sebagai pengajar berarti meneruskan dan mengembangkan ilmu dan pengetahuan dan teknologi kepada peserta didik. Tugas guru sebagai pelatih berarti mengembangkan keterampilan dan menerapkannya dalam kehidupan demi masa depan peserta didik.

Tugas kemanusiaan salah satu segi dari tugas guru. Sisi ini tidak biasa guru abaikan, karena guru harus terlibtat dengan kehidupan di masyarakat dengan interaksi sosial. Guru harus menanamkan nilai-nilai kemanusiaan kepada peserta [4]didik. Dengan begitu peserta didik diharapkan mempunyai sifat kesetiakawanan sosial. 
Di dalam masyarakat sekitar yaitu masyarakat kampung, desa tempat tinggalnya guru seringkali terpandang sebagai tokoh suri teladan bagi orang-orang sekitarnya, baik dalam sikap dan perbuatannya misalnya cara dia berpakaian, berbicara dan bergaul, maupun pandanganpandanganya, pendapat atau buah pikirannya seringkali menjadi ukuran atau pedoman kebenaran bagi orang-orang sekitarnya karena dianggap belum memiliki pengetahuan yang luas dan mendalam tentang berbagai hal.

\section{B. Hakikat Guru Pendidikan Agama Islam}

Sebagaimana telah dijelaskan di atas, bahwa seorang guru adalah orang yang bertugas membantu murid untuk mendapatkan pengetahuan sehingga dapat mengembangkan potensi yang dimiliki peserta didik. Sedangkan yang dimaksud guru pendidikan agama Islam adalah usaha orang dewasa muslim yang bertakwa secara sadar mengarahkan dan membimbing pertumbuhan serta perkembangan fitrah (kemampuan dasar) anak didik melalui ajaran Islam kearah titik maksimal pertumbuhan dan perkembangannya (M. Arifin, 1994:32).

Dalam islam tugas seorang pendidik dipandang suatu yang sangat mulia. Pendidik adalah bapak rohani (spiritual father) bagi peserta didik, yang memberikan santapan jiwa dengan ilmu. Pemabinaan akhlak yang mulia, dan meluruskam perilaku yang buruk. Posisi ini menyebabkan islam menempatkan orang yang beriman dan berilmu pengetahuan, lebih tinggi derajatnya dibandimgkan dengan manusia yang lain. 
Menurut Ahmad D. Marimba, tugas pendidik dalam pendidikan islam adalah membimbing, mengenal kebutuhan peserta didik, menciptakan situasi yang kondusif bagi kelangsungan proses pembelajaran, menambah dan mengembangkan pengetahuan peserta didik. Selain itu menurut Al-Ghazali tugas seorang pendidik adalah sebagai penunjuk jalan dan pembimbing keagamaan, sebagai sentral figur bagi murid, sebagai motivator bagi murid, sebagai seseorang yang memahami tingkat perkembangan intelektual murid, serta sebagai teladan bagi murid.

Sesungguhnya seorang pendidik tidak hanya bertugas saja, tetapi pendidik juga bertanggung jawab atas peserta didiknya, oleh karena itu tugas dan tanggung jawab pendidik dalam pendidikan dapat di simpulkan menjadi tiga, yaitu Sebagai pengajar (intruksional) yang bertugas merencanakan program pengajaran dan melaksanakan program yang telah disusun serta mengakhiri dengan pelaksanaan penilaian setelah program dilakukan. Juga sebagai pendidik (educator) yang mengarahkan peserta didik pada tingkat kedewasaan dan berkepribadian kamil seiring dengan tujuan Allah SWT menciptakanya. Serta sebagai pemimpin (managerial) yang memimpin, mengendalikan diri sendiri, peserta didik, dan masyarakat yang terkait terhadap berbagai masalah yang menyangkut upaya pengarahan, pengawasan. Pengorganisasian, pengontrnlan, dan partisipasi program pendidikan yang berlaku.

Sebagaimana tugas dan fungsi yang diemban cukup berat oleh para pendidik, sepatutnyalah dia dapat menjadikan dirinya sosok yang utuh dan tahu dengan kewajiban dan tanggung jawab sebagai seorang 
pendidik. Pendidik harus mengenal Allah dan Rasul, serta memahami risalah yamg dibawa.

Pendidik merupakan model manusia yang ditiru, di contoh dan di teladani jika terlanjur dan terpaksa melakukan kesalahan ia harus berani introspeksi diri, minta maaf, kemudian memperbaiki kesalahanya. Para ahli pendidikan telah banyak merumuskan sifat sifat atau kepribadian yang harus dimiliki oleh seorang pendidik antara lain Zuhud yang artinya pendidik tidak mengutamakan materi dan melakukanya karena Allah semata. Seorang pendidik dalam islam hendaknya tidak materialistis dalam terhadap dunia dan tidak mengukur segala sesuatu dengan harta (materi), meskipun demikian tidak berarti tidak mau menerima upah hasil kerjanya. Selain itu, seorang pendidik harus ikhlas dalam pekerjaanya. Seorang pendidik dituntut memiliki keikhlasan sebab keikhlasan merupakan salah satu sebab menuju kesuksesan. Karakter selanjutnya adalah bersifat pemaaf, sabar, dan mampu mengendalikan dirinya. Seorang pendidik harus mencintai anak didiknya seperti ia mencintai anaknya sendiri dan menikirkan keadaan merdka sebagaimana memikirkan anaknya sendiri. Harus mampu mengetahui tabiat anak didiknya dengan cara observasi, wawancara, melalui pergaulan. Yang tidak kalah penting adalah pendidik haus bisa bersifat adil, yaitu tidak membedakan peserta didiknya antara satu dengan yang lainnya.

\section{Standar Kompetensi Guru}

Kompetensi guru merupakan perpaduan antara kemampuan personal, keilmuan, teknologi, sosial, dan spiritual yang secara kaffah 
membentuk kompetensi standar profesi guru, yang mencakup penguasaan materi, pemahaman terhadap peserta didik, pembelajaran yang mendidik, pengembangan pribadi dan profesionalisme (Mulyasa, 2008:26). Dari uraian tersebut, nampak bahwa kompetensi mengacu pada kemampuan melaksanakan sesuatu yang diperoleh melalui pendidikan. Kompetensi merupakan komponen utama dari standar profesi disamping kode etik yang mengatur perilaku profesi sebagai seorang guru yang ditetapkan sebagai prosedur dan system pengawasan tertentu. Dalam hal ini kompetensi dimaknai sebagai perangkat perilaku efektif yang mengarahkan seorang guru menemukan cara-cara guna mencapai tujuan tertentu secara efektif dan efisien.

Standar kompetensi guru adalah suatu ukuran yang ditetapkan atau dipersyaratkan dalam bentuk penguasaan, pengetahuan dan perilaku perbuatan bagi seorang guru agar berkelayakan untuk menduduki jabatan fungsional sesuai dengan bidang tugas, kualifikasi, dan jenjang pendidikan (Suparlan, 2005:203). Standar kompetensi guru bertujuan untuk memperoleh acuan baku dalam pengukuran kinerja guru untuk mendapatkan jaminan kualitas guru dalam meningkatkan kualitas preses pembelajaran (Abdul Majid, 2008:6). Dengan demikian, kompetensi yang dimiliki oleh setiap guru akan menunjukkan kualitas guru dalam proses mengajar. Baik dalam penguasaan materi, pemahaman terhadap peserta didik, keprofesionalan dan sosok guru yang menjadi panutan bagi peserta didik. Kehadiran guru dalam proses belajar mengajar memegang peranan penting dan menempati kedudukan sentral. Oleh sebab itu guru diharuskan memiliki dan menguasai berbagai kompetensi keguruan 
dalam melaksanakan tugas dan tanggung jawabnya sebagai tenaga pendidik. Menurut Undang-Undang No. 14 tahun 2005 tentang Guru dan Dosen pasal 10 ayat (1) kompetensi guru meliputi: kompetensi pedagogik, kompetensi kepribadian, kompetensi sosial dan kompetensi profesional yang diperoleh melalui pendidikan profesi (Undang-undang republik Indonesia Nomor 14 tahun 2005 tentang guru dan dosen Pasal 10, 2005:7). Pada umumnya keempat kompetensi diatas tidak bisa berdiri sendiri, tetapi saling berhubungan dan saling mempengaruhi satu sama lainnya. Namun dalam proses pembelajaran, kompetensi pedagogik mempunyai peranan yang sangat penting karena berhubungan langsung dengan tugas pokok seorang guru, yakni sebagai pengelola proses pembelajaran.

Segaia guru, harusb memenuhi kompetensi utama guru sehingga benarObenar menjadi guru yang bermutu dalam mendidik generasi bangsa. Empat kompetensi utama tersebut adalah sebagai berikut:

Kompetensi yang pertama adalah kompetensi pedagogik, yang merupakan kemampuan guru dalam mengelola pembelajaran, sekurangkurangnya meliputi pemahaman wawasan atau landasan kependidikan, pemahaman terhadap peserta didik, pengembangan kurikulum/silabus, perencanaan pembelajaran, pelaksanaan pembelajaran yang mendidik dan dialogis, pemanfaatan teknologi pembelajaran, evaluasi proses dan hasil belajar, serta pengembangan peserta didik untu mengaktualisasikan berbagai potensi yang dimiliki

Kompetensi kedua adalah ompetensi kepribadian. Kompetensi kepribadian sekurang-kurangnya mencakup berakhlak mulia, arif dan 
bijaksan, mantab, berwibawa, stabil, dewasa, jujur, serta mampu menjadi teladan bagi peserta didik dan masyarakat

Kompetensi selanjutnya adalah kompetensi sosial yang merupakan kemampuan guru sebagai bagian dari masyarakat, sekurangkurangnya meliputi berkomunikasi lisan, tulisan, dan atau isyarat, menggunakan teknologi komunikasi dan informasi secara fungsional, bergaul secara efektif dengan peserta didik, sesama pendidik, tenaga kependidikan, pimpinan satuan pendidikan, orang tua/wali peserta didik, bergaul secara santun dengan masyarakat sekitar dengan mengindahkan norma serta sistem nilai yang berlaku, serta menerapkan prinsip-prinsip persaudaraan dan semangat kebersamaan.

Kompetensi professional menjadi kompetensi keempat yang harus dimiliki seorang guru. Kompetensi professional merupakan kemampuan guru dalam menguasai pengetahuan bidang ilmu teknologi dan seni yang sekurang-kurang meliputi penguasan materi pelajaran secara luas dan mendalam sesuai standar isi program satuan pendidikan, mata pelajaran, dan kelompok mata pelajaran yang diampunya. Selain itu juga penguasaan tentang konsep-konsep dan metode disiplin keilmuan, teknologi, atau seni yang relevan yang secara konseptual menaungi atau koheren dengan program satuan pendidikan, mata pelajaran, dan kelompok mata pelajaran yang diampu (Jamal Ma'mur Asmani, 2009:4345).

Kompetensi guru merupakan perpaduan antara kemampuan personal, keilmuan, teknologi, sosial, dan spiritual yang secara kaffah membentuk kompetensi standar profesi guru, yang mencakup 
penguasaan meteri, pemahaman terhadap peserta didik, pembelajaran yang mendidik, pengembangan pribadi dan pfofesionalisme (Mulyasa, 2008:26).

\section{Kompetensi Pedagogik}

Istilah kompetensi pedagogik dalam pembahasan didunia pendidikan muncul baru-baru ini dan masih diperbincangkan serta terdapat pembahasan yang hangat. Kompetensi pedagogik merupakan bagian dari kompetensi guru yang terdiri dari 4 kompetensi, yaitu: kompetensi professional, kompetensi kepribadian, kompetensi sosial, dan kompetensi pedagogik. Kompetensi merupakan seperangkat yang harus dimiliki oleh seorang guru, agar dapat melaksanakan tugas mengajar dengan berhasil (Hamzah, 2008:18).

Menurut Permendiknas Nomor 16 Tahun 2007, kompetensi pedagogik guru terdiri atas 37 buah kompetensi, yang dirangkum dalam 10 kompetensi inti, yaitu: menguasai karakteristik peserta didik dari aspek fisik, moral, spiritual, sosial, kultural, emosional,dan intelektual, lalu menguasai teori belajar dan prinsip-prinsip pembelajaran yang mendidik, mengembangkan kurikulum yang terkait dengan mata pelajaran yang diampu, menyelenggarakan pembelajaran yang mendidik, memanfaatkan teknologi informasi dan komunikasi untuk kepentingan pembelajaran, menfasilitasi pengembangan potensi peserta didik untuk mengaktualisasikan berbagai potensi yang dimiliki, berkomunikasi secara efektif, empatik, dan santun dengan peserta didik, menyelenggarakan penilaian dan evaluasi proses dan hasil belajar, memanfaatkan hasil 
penilaian dan evaluasi untuk kepentingan pembelajaran serta melakukan tindakan reflektif untuk peningkatan kualitas pembelajaran (permendiknas nomor 16 tahun 2007:1820).

Masalah kompetensi guru merupakan urgen yang harus dimiliki oleh setiap guru dalam jenjang pendidikan apapun. Guru yang trampil mengajar tentu harus memiliki kemampuan mengelola pempelajaran yang baik. Kompetensi pedagogik guru sangat penting diterapkan dalam rangka penyelenggaraan unsur-unsur pendukung kompetensi pendidikan diantaranya adalah kompetensi pedagogik sebagai alat penerimaan guru, kompetensi pedagogik penting dalam rangka pembinaan guru, kompetensi pedagogik penting dalam rangka penyusunan kurikulum, serta kompetensi pedagogik penting dalam hubungan dengan kegiatan dan hasil belajar (hamalik, 1991:27).

Dari pendapat di atas jelas bahwa kompetensi pedagogik mempunyai peranan penting dalam peningkatan kualitas pembelajaran. Oleh karena itu hendaknya setiap guru, termasuk guru pendidikan agama islam mutlak menguasai kompetensi pedagogik.

E. Analisis Kompetensi Pedagogik Guru Pendidikan Agama Islam di Sekolah Menengah Atas (SMA) se-Kecamatan Bringin Kabupaten Semarang Tahun 2012

1. Analisis Kompetensi Pedagogik Guru Pendidikan Agama Islam di Sekolah Menengah Atas (SMA) Negeri 1 Bringin Kabupaten Semarang Tahun 2012 
Kompetensi pedagogik sebagaimana yang sudah diuraikan dalam bab 2, adalah kompetensi yang mengatur pengelolaan guru dalam pembelajaran. Dari hasil penelitian yang dilakukan di sekolah menengah atas (SMA) Negeri 1 Bringin terdapat 2 orang guru pendidikan agama Islam. Dari hasil temuan dilapangan kompetensi pedagogik guru pendidikan agama islam di sekolah menengah atas (SMA) Negeri 1 Bringin sudah melaksanakan tugas dan kewajibannya sebagai guru dengan melaksanakan pengelolaan pembelajaran yang menjadi aturannya. Hal ini dibuktikan kedua guru pendidikan agama tersebut sudah linier dengan bidang keahliaanya. Selain itu dalam proses pembelajaran guru-guru pendidikan agama Islam di sekolah menengah atas (SMA) Negeri 1 Bringin melaksanakan pengelolaan pembelajaran dengan mempersiapkan perangkat pembelajaran terlebih dahulu, hal ini dibuktikan dengan hasil wawancara dengan JH berkenaan dengan proses pembuatan perangkat pembelajaran dan pemahaman guru terhadap karakteristik siswa, beliau menuturkan: "“Perencanaan pembelajaran tentu saya buat, karena itu merupakan tanggung jawab sebagai guru, selain itu juga merupakan tuntutan dari sekolah. Kalau untuk memahami karakteristik siswa saat pembelajaran kan kita berinteraksi langsung dengan siswa, secara tidak langsung kita bisa memahami kebutuan dan menyesuaikan dengan keadaan siswa" Hal yang sama juga diungkapkan oleh guru pendidikan agama Islam yang lain dan kepala sekolah menengah atas (SMA) Negeri 1 Bringin.

Dari hasil pengamatan yang dilakukan dengan narasumber tersebut, dapat dikatakan kompetensi pedagogik yang dimiliki guru 
pendidikan agama Islam di sekolah menengah atas (SMA) Negeri 1 Bringin Kabupaten Semarang memiliki kompetensi pedagogik yang sudah sesuai dengan aturan, hal ini terbukti dengan hasil wawancara dengan guru pendidikan agama Islam dan kepala sekolah tentang pemahaman kompetensi pedagogik guru pendidikan agama Islam yang baik dan dibuktikan dengan perangkat pembelajaran yang ada.

\section{Kompetensi Pedagogik Guru Pendidikan Agama Islam di Sekolah Menengah Atas (SMA) Islam Sudirman Bringin Kabupaten Semarang Tahun 2012}

Di sekolah menengah atas (SMA) Islam Sudirman Bringin terdapat seorang guru pendidikan agama Islam. Dari hasil temuan peneliti, guru pendidikan agama tersebut sudah linier dengan beban tugas yang menjadi tanggung jawabnya, yaitu dengan kepemilikan ijasah setrata 1 jurusan pendidikan agama Islam. Hal ini dibuktikan dengan wawancara kepada MZ, dimana beliau menuturkan: "Latar belakang pendidikan saya S1 pendidikan agama islam lulusan STAIN Salatiga Tahun 2000" Selain itu sebelum kegiatan pembelajaran berlangsung guru pendidikan agama Islam di sekolah menengah atas (SMA) Islam Sudirman juga mempersiapkan perangkat pembelajaran, hal ini dibuktikan dengan hasil wawancara kepada MZ, beliau menuturkan: "Perangakat pembelajaran saya buat, walau kadangkadang saya mengopi dari sekolah lain dan saya edit, saya sesuaikan dengan kondisi dan karakteristik siswa"

Dari penuturan $\mathrm{MZ}$ tersebut, terlihat bahwa persiapan dalampembuatan perangkat pembelajaran yang dilakukan guru 
pendidikan agama Islam belum maksimal, dibuktikan dengan penuturan MZ yang dalam pembuatan perangkat pembelajaran masih mengopi dari sekolah lain meski diubah dan disesuiakan dengan kondisi siswa dan sekolah. Dari berbagai penuturan informan diatas dapat dipahami kompetensi pedagogik yang dimiliki guru pendidikan agama Islam di sekolah menengah atas (SMA) Islam Sudirman Bringin Kabupaten Semarang memiliki kompetensi pedagogik yang sudah sesuai dengan aturan, meski masih ada beberapa hal yang belum terpenuhi sesuai dengan komponen-komponen kompetensi pedagogik sebagaimana yang dituliskan dalam bab 2, yaitu kecakapan pembuatan perangkat pembelajaran yang belum maksimal.

\section{F. Analisis Upaya Guru Pendidikan Agama Islam Dalam Meningkatkan Kompetensi Pedagogik di Sekolah Menengah Atas (SMA) se-Kecamatan Bringin Kabupaten Semarang tahun 2012}

1. Analisis Upaya Guru Pendidikan Agama Islam Dalam Meningkatkan Kompetensi Pedagogik di Sekolah Menengah Atas (SMA) Negeri 1 Bringin Kabupaten Semarang Tahun 2012

Dari hasil pengamatan dan wawancara yang dilakukan penulis, berbagai upaya yang dilakukan baik dari pihak guru langsung maupun dari pihak kepala sekolah. Sebagaimana yang diungkapkan MM mengenai upaya yang dilakukan guru pendidikan agama Islam dalam meningkatkan kompetensi pedagogik "Dari pengalaman-pengalaman yang ada, saya mengajar kan sudah cukup lama, itu saya jadikan pelajaran kedepannya bagaimana memahami siswa itu, mengikuti 
worksop, seminar, penataran, banyak membaca buku selain itu dalam musyawarah guru mata pelajaran(MGMP) pendidikan agama islam juga sering membahas bagaimana cara mengajar yang baik, mencari solusi dari kesulitan-kesulitan yang ada" Hal yang sama juga diungkapkan oleh guru pendidikan agama Islam yang lainnya. Dapat disimpulkan guru pendidikan agama Islam di sekolah menengah atas (SMA) Negeri 1 Bringin melakukan pengelolaan pembelajaran dengan baik, melakukan berbagai upaya dalam meningkatkan kompetensi pedagogik dengan cara membaca berbagai referensi buku yang berkenaan dengan kompetensi pedagogik guru pendidikan agama islam, mengikuti berbagai seminar, worksop, pelatian-pelatian, dan mengikuti musyawarah guru mata pelajaran (MGMP) guru pendidikan agama islam. Selain upaya dari pihak guru pendidikan agama Islam, dari pihak sekolah juga melakukan berbagai upaya guna meningkatkan kompetensi pedagogik guru pendidikan agama Islam, melalui evaluasi pembelajaran, pengecekan perangkat pembelajaran, supervisi kelas, dan pemberian kesempatan kepada guru untuk mengikuti seminar-seminar pendidikan.

\section{Analisis Upaya Guru Pendidikan Agama Islam Dalam Meningkatkan Kompetensi Pedagogik di Sekolah Menengah Atas (SMA) Islam Sudirman Bringin Kabupaten Semarang Tahun 2012}

Dari hasil wawancara dan pengamatan yang penulis lakukan terhadap informan berbagai upaya yang dilakukan dalam meningkatkan kompetensi pedagogik guru pendidikan agama islam, sebagaimana MZ menuturkan: "Dari pengalaman-pengalaman selama mengajar ini 
dijadikan evaluasi untuk lebih meningkatkan kompetensi pedagogik, baca-baca buku, mengikuti MGMP, ikut seminar-seminar pendidikan" Selain upaya dari guru sendiri, dari pihak kepala sekolah juga berupaya meningkatkan kompetensi pedagogik diantaranya melalui evaluasi proses pembelajaran dari kepala sekolah, pengecekan perangkat pembelajaran, maupun pemberian kesempatan terhadap guru pendidikan agama Islam mengikuti pelatihan-pelatihan keguruan untuk meningkatkan kompetensi pedagogik yang dimilikinya.

G. Analisis Implementasi Kompetensi Pedagogik Pada Pembelajaran Pendidikan Agama Islam di Sekolah Menengah Atas(SMA) se-Kecamata Bringin Kabupaten Semarang tahun 2012

\section{Analisis Implementasi Kompetensi Pedagogik Pada} Pembelajaran Pendidikan Agama Islam di Sekolah Menengah Atas (SMA) Negeri 1 Bringin Kabupaten Semarang Tahun 2012

Apabila guru memiliki kemampuan mengelola pembelajaran yang baik pasti berdampak pada pembelajaran yang baik pula. Dari hasil penelitian yang dilakukan, ternyata banyak sekali manfaat yang dirasakan dengan adanya kompetensi pedagogik, dari hasil wawancara yang dilakukan baik dengan guru pendidikan agama Islam maupun kepala sekolah adalah dengan adanya guru yang memiliki kompetensi pedagogik pengelolaan pembelajaran akan berjalan dengan lancar, siswa lebih mudah menerima materi yang diajarkan oleh guru, dan hasil yang dicapai dalam pembelajaran akan maksimal. Hai ini terbukti dari hasil wawancara dengan narasumber, salah satunya dengan $\mathrm{JH}$, menuturkan: 
"Implementasi kompetensi pedagogik terhadap keberhasilan bembelajaran itu sangat berpengaruh, tanpa guru yang kompeten pembelajaran tidak akan berhasil, namun dalam pelaksanaannya banyak sekali hambatannya, termasuk kemampuan siswa yang kurang maksimal" Dari penjelasan tersebut dapat dipahami bahwa kompetensi pedagogik akan berdampak pada keberhasilan pembelajaran, pengelolaan pembelajarn yang baik akan menghasilkan mutu pembelajaran yang baik juga.

\section{Analisis Implementasi Kompetensi Pedagogik Pada} Pembelajaran Pendidikan Agama Islam di Sekolah Menengah Atas (SMA) Islam sudirman Bringin Kabupaten Semarang Tahun 2012

Implementasi kompetensi pedagogik pada pembelajaran pendidikan agama islam disekolah menengah atas (SMA) Islam Sudirman Bringin sebagaimana yang telah diungkapkan dalam bab 3 bahwa implementasi kompetensi pedagogik sangat berpengaruh pada keberhasilan terhadap pembelajaran pendidikan agama Islam, guru yang memiliki kompetensi pedagogik yang baik akan dapat mengelola pembelajaran yang baik juga, yang akan berdampak pada keberhasilan dalam pembelajaran. Sebagaimana ET, menuturkan sebagai berikut: "Kalau gurunya berkompeten dalam mengajar, pasti dalam pembelajarn juga akan berhasil. Guru bisa menerapkan metode-metode pembelajaran yang sesuai, pembelajaran juga akan menyenangkan bagi siswa" Dapat disimpulkan kompetensi pedagogik memegang peranan yang penting 
dalan keberhasilan pembelajaran, guru yang melakukan pengelolaan pembelajaran yang baik, akan menghasilkan kualitas pembelajaran yang baik juga.

\section{KESIMPULAN}

Berdasarkan laporan penelitian dan pembahasan dapat dirumuskan kesimpulan penelitian sebagai berikut:

Pertama, kompetensi pedagogik guru pendidikan agama Islam di sekolah menengah atas(SMA) se-Kecamatan Bringin Kabupaten Semarang Tahun 2012, dari hasil pembahasan di atas dapat disimpulkan bahwa kompetensi pedagogik guru pendidikan agama islam di sekolah menengah atas (SMA) se-Kecamatan Bringin sudah dianggap baik, dengan dibuktikan dari kepemilikian latar belakang kependidikan, pemahaman guru pendidikan agama Islam terhadap kompetensi pedagogik yang baik, penyusunan perangkat pembelajaran dan pengelolaan pembelajaran yang sesuai dengan ketentuan.

Kedua, upaya guru pendidikan agama islam dalam meningkatkan kompetensi pedagogik di sekolah menengah atas (SMA) se Kecamatan Bringin Kabupaten Semarang Tahun 2012, dapat disimpulkan guru pendidikan agama Islam se Kecamatan Bringin melakukan pengelolaan pembelajaran dengan baik, melakukan berbagai upaya dalam meningkatkan kompetensi pedagogik dengan cara membaca berbagai referensi buku yang berkenaan dengan kompetensi pedagogik guru pendidikan agama Islam, mengikuti berbagai seminar, worksop, pelatianpelatian, dan mengikuti musyawarah guru mata pelajaran (MGMP) guru 
pendidikan agama Islam. Selain upaya dari pihak guru pendidikan agama Islam, dari pihak sekolah juga melakukan berbagai upaya guna meningkatkan kompetensi pedagogik guru pendidikan agama Islam, melalui evaluasi pembelajaran, pengecekan perangkat pembelajaran, supervisi kelas, dan pemberian kesempatan kepada guru untuk mengikuti seminarseminar pendidikan.

Ketiga, implementasi kompetensi pedagogik pada pembelajaran Pendidikan Agama Islam di sekolah menengah atas (SMA) se Kecamatan Bringin Kabupaten Semarang Tahun 2012, implementasi kompetensi pedagogik pada pembelajaran pendidikan agama Islam akan menentukan mutu dari pembelajaran itu sendiri. Dari hasil pembahasn, dengan adanya guru yang memiliki kompetensi pedagogik pengelolaan pembelajaran akan berjalan dengan lancar, siswa lebih mudah menerima materi yang diajarkan oleh guru, dan hasil yang dicapai dalam pembelajaran akan maksimal.

\section{Daftar Pustaka}

Arief, Armai. 2002. Pengantar Ilmu dan Metodologi Pendidikan Islam. Jakarta: Ciputat Press.

Arifin, M. 1994. Ilmu Pendidikan Islam. Jakarta: Bumi Aksara.

Asmani, Jamal Makmur 2009. 7 Kompetensi Guru Menyenangkan dan Professional. Yogyakarta: power Books (IHDINA).

B. Uno, Hamzah. 2008. Profesi Kependidikan. Jakarta: Bumi Aksara.

Departemen Agama Republik Indonesia. 2005. Al-Qur'an dan Terjemahnya. Surabaya: CV Karya Utama.

Djamarah, Syaiful Bahri. 2000. Guru dan Anak Didik dalam Interaksi Edukatif. Jakarta: PT Rineka Cipta.

Hamalik, Oemar. 1991. Pendidikan Guru Konsep dan Strategi. Bandung: Mandar Maju. 
Majid, Abdul. 2008. Perencanaan Pembelajaran Mengembangkan Standar Kompetensi Guru. Bandung: PT Remaja Rosda Karya.

Mulyasa, E. 2008. Standar Kompetensi dan Sertifikasi Guru. Bandung: PT Remaja Rosda Karya.

Pusat Bahasa Departemen Pendidikan Nasional. 2007. Kamus Besar Bahasa Indonesia edisi ketiga. Jakarta: Departemen Pendidikan Nasional Balai Pustaka.

Redaksi Sinar Grafika. 2006. Undang-Undang Guru dan Dosen (UU RI No 14 Tahun 2005). Jakarta: Sinar Grafika.

Roqib, Moh. 2009. Ilmu Pendidikan Islam (Pengembangan Pendidikan Integratif, Sekolah, Keluarga dan Masyarakat). Yogyakarta: PT LKIS Printing.

Sembiring, Sentosa. 2006. Himpunan Perundang-Undangan Republik Indonesia Tentang Guru dan Dosen. Bandung: CV Nuansa Aulia.

Suparlan. 2005. Menjadi Guru Efektif. Yogyakarta: Hikayat Publising.

Surakhmad, Winarno. 1986. Pengantar Penelitian Ilmiah. Bandung: Tarsito.

Yasin, A. Fatah. 2008. Dimensi-Dimensi Pendidikan Islam. Malang: UIN Malang Press.

Zuriah, Nurul. 2007. Metodologi Pendidikan Sosial dan Pendidikan. 